\title{
KINERJA DAN EFISIENSI RANTAI PASOK (SUPPLY CHAIN) NANAS DI DESA TANGKIT BARU KECAMATAN SUNGAI GELAM KABUPATEN MUARO JAMBI
}

\author{
Mirawati Yanita* dan Ira Wahyuni \\ Fakultas Pertanian Universitas Jambi \\ Jl. Kemajuan, Mendalo Darat, Jambi Luar Kota, Muaro Jambi, Jambi 36361 \\ *Corresponding author: mirawatiyanita@unja.ac.id
}

\begin{abstract}
This study aimed to analyze the pineapple supply chain's performance and efficiency in Tangkit Baru Village, Sungai Gelam District, Muaro Jambi Regency. The data used in the study was primary data, obtained from direct interviews using questionnaires to 76 respondents consisting of 56 farmers, and 20 marketing agencies involved in pineapple marketing in Tangkit Baru Village from October to December 2019. Pineapple supply chain performance is measured based on marketing efficiency using marketing margin criteria, farmer's share, and profit-to-cost marketing ratio. The results showed that there are five pineapple marketing channels in Tangkit Baru Village that involve marketing actors ranging from farmers, large inter-city traders, village collectors, out-of-pick-up merchants, retailers and consumers. Based on the analysis of marketing efficiency, the marketing channel that has the smallest total margin distribution, the largest farmer share is 100 percent and the total profit-to-cost ratio of 32.2 percent is the 5 marketing channel, so channel 5 is the most efficient marketing channel.
\end{abstract}

Keywords: pineapple, FSCN, performance, supply chain efficiency.

\begin{abstract}
Abstrak: Tujuan dari penelitian ini adalah menganalisis kinerja dan efisiensi rantai pasok nanas di Desa Tangkit Baru Kecamatan Sungai Gelam Kabupaten Muaro Jambi. Data yang digunakan dalam penelitian yaitu data primer, yang diperoleh dari wawancara langsung menggunakan kuesioner kepada 76 responden yang terdiri dari 56 orang petani, dan 20 lembaga pemasaran yang terlibat dalam pemasaran nanas di Desa Tangkit Baru. Pelaksanaan penelitian pada Oktober sampai Desember 2019. Kinerja rantai pasok nanas diukur berdasarkan efisiensi pemasaran menggunakan kriteria marjin pemasaran, farmer's share, dan rasio keuntungan terhadap biaya pemasaran. Hasil penelitian menunjukkan bahwa terdapat lima saluran pemasaran nanas di Desa Tangkit Baru yang melibatkan pelaku pemasaran mulai dari petani, pedagang besar antar kota, pedagang pengumpul desa, pedagang luar jemput, pedagang pengecer dan konsumen. Berdasarkan analisis efisiensi pemasaran, saluran pemasaran yang memiliki sebaran total margin terkecil, farmer share terbesar yaitu sebesar 100 persen dan total rasio keuntungan terhadap biaya yang besar yaitu sebesar 32,2 persen adalah saluran pemasaran 5 , sehingga saluran 5 merupakan saluran pemasaran yang paling efisien.
\end{abstract}

Kata Kunci : nanas, FSCN, kinerja, efisiensi rantai pasok.

\section{PENDAHULUAN}

Hortikultura merupakan salah satu sebsektor dalam pertanian yang memiliki jenis komoditas yang beragam dam merupakaan sektor yang dibutuhkan masyarakat secara langsung. Tanaman hortikultura cocok untuk dibudidayakan di Indonesia. Tanaman hortikultura terdiri dari sayur-sayuran, buahbuahan, tanaman obat-obatan (biofarma) dan 
tanaman hias. Salah satu tanaman hortikultura yang berpotensial untuk dikembangkan di Indonesia adalah nanas. Potensi ini ditunjukkan dengan penyebaran buah nanas yang merata di Indonesia dan adanya beberapa sentra produksi nanas di Indonesia. Tanaman nanas tersebar hampir di seluruh wilayah Indonesia. Berdasarkan sentra penghasil nanas di Indonesia, provinsi Jambi menempati urutan ke enam sebagai sentra produksi nanas dengan jumlah rata-rata produksi pada tahun 20162017 sebanyak 118.016,25 atau sebesar 7,67\% dari total produksi nanas nasional.

Kabupaten Muaro Jambi merupakan kabupaten yang memiliki volume produksi nanas tertinggi di Provinsi Jambi dengan kontribusi sebesar $99,73 \%$ dari total rata-rata produksi di Provinsi Jambi. Namun, produksi buah nanas di Kabupaten Muaro Jambi cenderung mengalami penurunan produksi. Produksi nanas mengalami penurunan secara signifikan pada tahun 2014-2017, menunjukkan bahwa pengembangan budidaya nanas di Desa Tangkit Baru belum optimal dan masih terdapat permasalahan seperti, jalan pertanian yang kurang baik, tidak adanya jaminan harga tetap yang diterima petani, kurangnya informasi yang transparan mengenai perkembangan pasar, serta tingginya harga ditingkat konsumen.

Pengembangan tanaman nanas di Desa Tangkit Baru sangat prospektif berdasarkan potensi produksi dan wilayah pemasaran nanas hingga keluar Pulau Sumatera. Meskipun demikian, masih terdapat permasalahan yang dihadapi oleh petani nanas di Desa Tangkit Baru, di antaranya produktivitas dan harga nanas di tingkat petani relatif rendah serta berfluktuatif. Menurut (Drajat et al., 2007) bahwa kelemahan mendasar dalam pengembangan agribisnis perkebunan rakyat adalah sistem pemasaran yang belum efisien. Selain itu, keterbatasan pengetahuan yang dimiliki petani nanas terhadap teknik budidaya nanas merupakan salah satu penyebab rendahnya produktivitas nanas.

Secara umum pada pengembangan nanas tangkit di Desa Tangkit Baru Kecamatan Sungai Gelam masih ditemukan beberapa kendala seperti (1) ketersediaan buah nanas yang tidak merata setiap bulannya sehingga menyebabkan pasokan buah nanas melimpah pada saat panen raya dan terjadi kekurangan pasokan pada saat diluar panen raya, (2) kurangnya informasi yang dimiliki petani mengenai perkembangan harga nanas di pasar, menyebabkan harga nanas yang diterima petani lebih rendah dibanding harga akhir nanas di tingkat konsumen sehingga keuntungan yang diterima petani rendah, (3) petani sebagai penerima harga (price taker) menyebabkan peran pedagang lebih tinggi dalam menentukan harga dan mendapatkan keuntungan yang lebih besar.

Permasalah pemasaran nanas di Desa Tangkit Baru Kecamatan Sungai Gelam Kabupaten Muaro Jambi, adalah jarak tempuh yang cukup jauh ke titik pasar. Kondisi tersebut mengakibatkan adanya peluang kinerja pemasaran nanas yang tidak efisien. Oleh sebab itu, pemasaran yang efektif sangat dibutuhkan dalam pendistribusian nanas untuk meningkatkan harga jual nanas di tingkat petani. Harga jual nanas yang tinggi akan semakin memotivasi petani untuk meningkatkan produksi buah nanasnya. Perbaikan bidang pemasaran dengan memperkecil biaya pemasaran dan menciptakan harga jual sesuai dengan kemampuan daya beli konsumen dapat meningkatkan efisiensi pemasaran.

Rantai pasok (Supply chain) merupakan jaringan perusahaan yang secara bersama-sama berkerjasama untuk menciptakan dan mengantarkan produk sampai ke konsumen tingkat akhir (Nguyen, 2020). Rantai pasok berkaitan dengan alur distribusi barang mulai dari ditingkat petani sebagai produsen hingga sampai pada tingkat konsumen akhir. Untuk mengetahui seberapa baiknya kinerja rantai pasok nanas di Desa Tangkit Baru Kecamatan Sungai Gelam Kabupaten Muaro Jambi maka perlu dianalisis secara kualitatif dan kuantitatif.

\section{METODE PENELITIAN}

Penelitian ini dilakukan di Desa Tangkit Baru, Kecamatan Sungai Gelam, Kabupaten Muaro Jambi. Penentuan lokasi penelitian dilakukan secara sengaja (purposive), dengan pertimbangan bahwa Kecamatan Sungai Gelam merupakan salah satu kecamatan yang memiliki produksi nanas terbesar di Kabupaten Muaro Jambi, sedangkan pemilihan desa dilakukan di Desa Tangkit Baru yang merupakan sentra pengembangan sekaligus penghasil nanas 
tangkit terbesar yang memiliki luas lahan dan produksi tertinggi di Kecamatan Sungai Gelam, Kabupaten Muaro Jambi dengan rata-rata tanaman nanas berada pada masa produktif.

Sampel responden dalam penelitian ini adalah petani nanas yang melakukan usahatani nanas dan lembaga pemasaran nanas di Desa Tangkit Baru. Populasi dalam penelitian ini dipilih berdasarkan petani nanas yang tergabung dalam kelompok tani di Desa Tangkit Baru. Teknik pengambilan sampel pada penelitian ini dilakukan dengan cara Simple Random Sampling, dan Snowball Sampling. Metode Random Sampling digunakan untuk menentukan sampel petani nanas, pengambilan sampel dilakukan secara acak tanpa memperhatikan strata yang ada dalam populasi.

Pengumpulan data pada penelitian ini dilakukan pada bulan Oktober sampai Desember 2019. Data yang digunakan dalam penelitian ini adalah data primer. Data diperoleh dari hasil wawancara dengan petani nanas dan lembaga-lembaga yang terlibat didalam pemasaran nanas di Desa Tangkit Baru Kecamatan Sungai Gelam Kabupaten Muaro Jambi. Jumlah petani nanas yang dijadikan responden penelitian sebanyak 56 petani nanas yang tergabung dalam kelompok tani dan jumlah responden lembaga pemasaran sebanyak 20 orang yang sebagian besar berada di Desa Tangkit Baru kecuali Pedagang Besar Luar Kota dan Pedagang Luar Jemput, yaitu dengan rincian 4 Pedagang Pengumpul Desa Tunggu (PPDT), 3 Pedagang Besar Luar Kota (PBLK), 5 Pedagang Luar Jemput (PLJ), 2
Pedagang Pengumpul Desa Jemput (PPDJ), dan 6 Pedagang Pengecer (PP).

\section{Metode Analisis \\ Analisis pemasaran dilakukan dengan pendekatan food supply chain network (FSCN) dan pengukuran kinerja pemasaran menggunakan pendekatan efisiensi pemasaran.}

\section{Pendekatan Food Supply Chain Network (FSCN)}

Pendekatan system pemasaran yang digunakan dalam penelitian ini adalah pendekatan food supply chain network (FSCN) yang diadaptasi dari (Lambert dan Enz, 2017) yang kemudian dimodifikasi oleh (Vorst, 2014). Analisis menggunakan kerangka FSCN merupakan analisis yang biasa digunakan untuk menganalisis suatu rantai pasok pada produk pertanian dengan tujuan mendeskripsikan kondisi rantai pasok dan mendapatkan informasi mengenai sasaran rantai pasok, struktur rantai pasok, manajemen rantai pasok, sumber daya rantai pasok, dan proses bisnis rantai pasok nanas di Desa Tangkit Baru (Gambar 1). Kelima komponen dianalisis secara deskriptif kualitatif, sedangkan komponen kinerja dianalisis menggunakan metode deskriptif kuantitatif melalui perhitungan efisiensi pemasaran. Pengukuran kinerja dilakukan untuk mengoptimalkan jaringan pemasaran yang bertujuan menentukan langkah-langkah ke depan dalam hal strategi, taktik, dan operasional (Vorst, 2014).

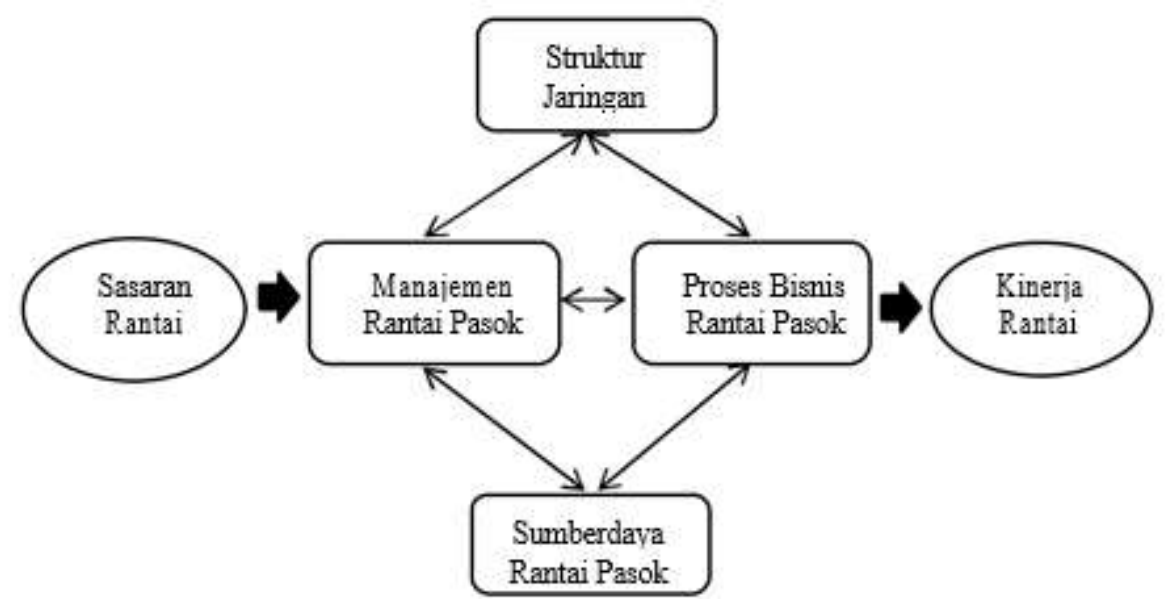

Gambar 1. Kerangka analisis deskriptif rantai pasok 


\section{Efisiensi Pemasaran}

Efisiensi pemasaran adalah tujuan yang ingin dicapai dalam sebuah kegiatan pemasaran. Terdapat dua pendekatan yang dapat digunakan untuk mengukur efisiensi pemasaran, yaitu efisiensi operasional dan efisiensi harga. Pendekatan efisiensi operasional seringkali digunakan karena mempertimbangkan fungsifungsi yang mampu meningkatkan rasio output terhadap input pemasaran (Dilana, 2013). Analisis efisiensi pemasaran dengan pendekatan operasional diukur dengan marjin pemasaran, farmer's share, dan rasio keuntungan terhadap biaya.

\section{a. Margin Pemasaran}

Analisis marjin digunakan untuk mengetahui biaya pemasaran yang menyebabkan adanya perbedaan harga jual diantara lembaga-lembaga pemasaran. Margin pemasaran merupakan perbedaan harga diantara lembaga pemasaran. Besarnya marjin pemasaran pada dasarnya merupakan penjumlahan dari biaya-biaya pemasaran dan keuntungan yang diperoleh dari lembaga pemasaran. Marjin pemasaran dapat dituliskan sebagai berikut :

$$
M i=P s i-P b
$$

Rumus untuk mencari keuntungan tiap lembaga yaitu sebagai berikut:

$P s i-P b i=C i+\pi i$

Maka besarnya margin pemasaran total adalah:

$M T=\sum M i$

Keuntungan lembaga pemasaran pada tingkat ke-i sebesar:

$\pi i=P s i-P b i-C i$

Keterangan :

$M i$ : Margin pada lembaga pemasaran nanas ke-i (Rp/Buah)

Psi : Harga jual pada lembaga pemasaran nanas ke-i (Rp/Buah)

$P b i$ : Harga beli pada lembaga pemasaran nanas sebelumnya (Rp/Buah)

$\Pi i$ : Keuntungan yang diperoleh lembaga pemasaran nanas ke-i (Rp/Buah)

$M T$ : Total margin pemasaran nanas (Rp/Buah)

$C i$ : Biaya lembaga pemasaran nanas tingkat ke-i (Rp/Buah)

I : $1,2,3 \ldots . .(\mathrm{n})$

\section{b. Farmer's Share}

Indicator lain yang digunakan untuk mengukur efisiensi pemasaran adalah Farmer's share, yaitu membandingkan harga yang diterima oleh petani dengan harga yang dibayarkan oleh konsumen. Farmer's share berhubungan negative dengan margin pemasaran, artinya semakin rendah margin pemasaran maka bagian yang akan diperoleh petani (farmer's share) semakin tinggi. Farmer's share dirumuskan sebagai berikut :

$F S=\frac{P f}{P r} \times 100 \%$

Keterangan :

Fs : Farmer's Share atau persentase bagian yang diterima petani nanas (\%)

$\operatorname{Pr}$ : Harga yang dibayar konsumen akhir (Rp/Buah)

Pf : Harga ditingkat petani (Rp/Buah)

c. Rasio Keuntungan terhadap Biaya

Rasio keuntungan terhadap biaya merupakan besarnya keuntungan yang diterima lembaga pemasaran sebagai imbalan atas biaya pemasaran yang telah dilakukan. Nilai rasio keuntungan dan biaya sama dengan satu menunjukkan bahwa biaya yang dikeluarkan sama besar dengan keuntungan yang diperoleh. Semakin seimbang dan merata rasio keuntungan terhadap biaya di setiap lembaga pemasaran mengindentifikasikan bahwa secara operasional kegiatan pemasaran semakin efisien.

Rasio keuntungan terhadap biaya $=$

$\frac{\pi \mathrm{i}}{\mathrm{Ci}} \times 100 \%$

Keterangan :

Пi : Keuntungan yang diperoleh lembaga pemasaran nanas ke-i (Rp/Buah)

$\mathrm{Ci}$ : Biaya lembaga pemasaran nanas tingkat ke-i (Rp/Buah)

\section{HASIL DAN PEMBAHASAN}

\section{Gambaran Rantai Pasok Nanas \\ 1. Sasaran Rantai Pasok}

Sasaran rantai pasok menjelaskan mengenai apa yang menjadi tujuan dalam rantai pasok nanas di Desa Tangkit Baru Kecamatan Sungai Gelam, Kabupaten Muaro Jambi yang dapat dilihat dari dua sisi yaitu sasaran pasar dan sasaran pengembangan.

a. Sasaran Pasar

Sasaran buah nanas di Desa Tangkit Baru didominasi untuk memenuhi kebutuhan pasar domestik. Produk akhir yang dihasilkan dalam rantai pasok nanas di Desa Tangkit Baru 
sebagian besar berupa buah nanas segar. Sasaran pasar nanas Desa Tangkit Baru adalah konsumen akhir yang berada di pasar-pasar sekitar Kota Jambi seperti, Pasar Angso Duo, Pasar Talang Banjar, di tepi jalan simpang rimbo, selain di pasar sekitar Kota Jambi pelaku rantai pasok juga memasarkan nanas ke beberapa daerah seperti Tebo, Bungo, Tungkal, Curup, Linggau, Padang dan daerah luar kota seperti Jakarta dan Bandung. Penelitian membatasi wilayah penelitian hanya sampai konsumen akhir di pasar sekitaran Kota Jambi karena sudah dapat mewakili penelitian yaitu kesamaan pola/saluran rantai pasok. Sasaran pasar nanas di Desa Tangkit Baru yang dipasarkan merupakan buah nanas segar yang digunakan untuk dikonsumsi secara langsung maupun diolah oleh konsumen akhir.

\section{b. Sasaran Pengembangan.}

Sasaran pengembangan yang ingin dicapai di dalam pemasaran nanas di Desa Tangkit Baru adalah peningkatan kualitas dan kuantitas nanas yang dihasilkan oleh petani. Sasaran pengembangan yang dapat dicapai pada rantai pasok nanas di Desa Tangkit Baru yakni peningkatan kualitas buah nanas, yaitu dengan menghasilkan buah nanas yang berukuran besar serta memiliki rasa yang lebih manis sehingga harga yang diterima petani lebih tinggi. Kesadaran petani untuk meningkatkan kualitas buah nanas masih kurang karena pembeli nanas di Desa Tangkit Baru masih menerima semua jenis nanas yang dihasilkan oleh petani nanas meskipun dengan harga yang lebih rendah.

\section{Struktur Rantai Pasok}

Anggota pemasaran merupakan para pelaku yang terlibat dalam aliran produk, aliran finansial, dan aliran informasi dari mulai petani sebagai produsen sampai pada konsumen akhir (Vorst, 2014). Proses penyaluran produk dari produsen ke konsuen akhir memerlukan berbagai kegiatan fungsional pemasaran yang ditujukan untuk mempelancar proses penyaluran barang dan jasa secara efektif dan efisien (Rasihen, 2018).

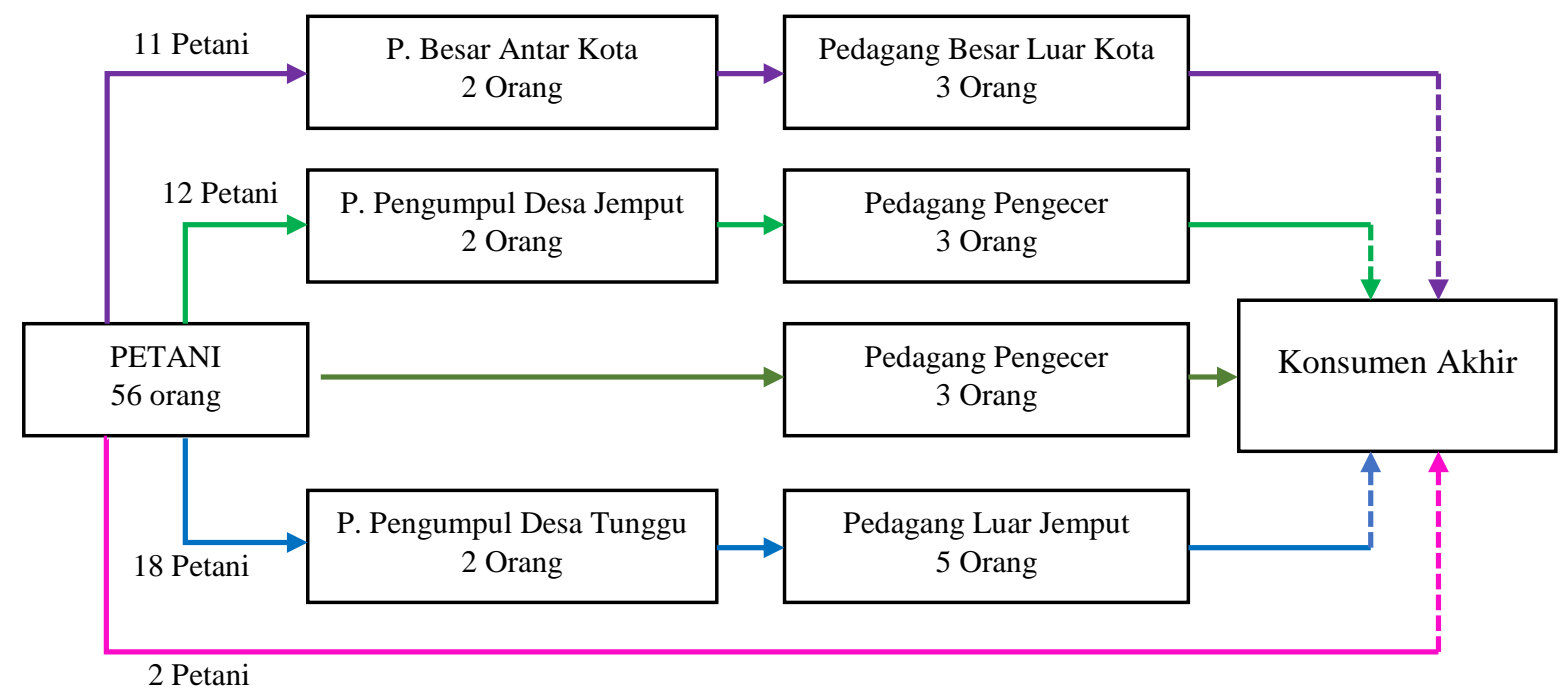

Keterangan :

Saluran 1 :

Saluran 2:

Saluran 3 :

Saluran 4 :

Saluran 5:

Hubungan Langsung :

Hubungan Tidak Langsung :

Gambar 2. Skema saluran rantai pasok nanas di Desa Tangkit Baru, Kecamatan Sungai Gelam,

Kabupaten Muaro Jambi Tahun 2019

Sumber : Data Primer Diolah, 2019 
Pada rantai pasok nanas di Desa Tangkit Baru terdapat 5 saluran pemasaran dengan anggota rantai pasok yang terdiri atas petani, pedagang pengumpul desa tunggu, pedagang pengumpul desa jemput, pedagang antar kota, pedagang luar jemput, pedagang pengecer, agroindustri dan konsumen. Adapun pola saluran pemasaran nanas di Desa Tangkit Baru Kecamatan Sungai Gelam Kabupaten Muaro Jambi dapat dilihat pada Gambar 2 .

\section{Manajemen Rantai Pasok}

Manajemen rantai pasok merupakan suatu proses perencanaan, pelaksanaan dan evaluasi yang dilakukan bersama oleh anggota rantai pasok dalam pemasaran nanas di Desa Tangkit Baru Kecamatan Sungai Gelam Kabupaten Muaro Jambi. Pemilihan mitra dilakukan oleh anggota rantai pasok dengan beberapa pertimbangan, seperti harga yang ditawarkan lebih baik, pihak yang sudah menjadi pelanggan, hubungan kekeluargaan, system pembayaran yang lancer dan dapat dipercaya, lokasi pedagang berdekatan dengan lokasi petani, dan transfaran tentang informasi seputar pemasaran. Kesepakatan kontraktual yang terjadi antara petani dengan pedagang pengumpul belum menggunakan kerjasama yang tertulis atau secara formal, melainkan kontrak yang dilakukan secara informal melalui kesepakatan lisan.

Secara umum, sistem transaksi yang dilakukan antara petani dan pedagang pengumpul desa, pedagang besar antar kota maupun pedagang pengecer dilakukan dengan dua cara yaitu sistem pembayaran tunai dan pembayaran kemudian atau tunda. Dukungan pemerintah dalam meningkatkan manajemen rantai pasok nanas antara lain bantuan pembuatan Tugu Nanas yang menjadi mascot dan kebanggan bagi masyarakat desa yang menjadi daya tarik untuk menyambut kehadiran pengunjung yang akan masuk kedesa itu, bantuan pupuk subsidi, bantuan motor pengangkut roda tiga untuk setiap kelompok tani, pembangunan jalan, pondokan nanas yang digunakan untuk memajang nanas yang dihasilkan petani.

Dukungan yang diberikan selanjutnya yaitu pemberian bimbingan dan pelatihan, pengarahan serta informasi yang dibutuhkan petani mengenai usahatani nanas melalui penyuluh pertanian dalam upaya pengaturan jarak tanam dan penggunaan pupuk organik untuk meningkatkan produktivitas nanas baik secara formal maupun dalam pertemuan kelompok tani, perbaikan infrastruktur jalan menuju desa untuk memudahkan pedagang dalam mendistribusikan nanas keluar desa, namun akses jalan petani menuju kebun nanas belum memadai untuk dilewati.

Kolaborasi atau koordinasi merupakan kegiatan saling bertukar informasi antar setiap anggota dalam rantai pasok. Informasi yang berasal dari konsumen akhir yang disampaikan kepada pedagang pengecer, disampaikan kepada pedagang pengumpul desa lalu selanjutnya akan disampaikan kepada petani sebagai pemasok utama dan begitu sebaliknya. Kolaborasi antar anggota rantai pasok terlihat dari adanya keterbukaan informasi antar pelaku yang terjalin secara timbal balik sebagai salah satu hal yang mendukung kelancaran aktivitas rantai pasok.

\section{Sumberdaya Rantai Pasok}

Sumberdaya rantai pasok sangat diperlukan untuk mendukung, mengembangkan, serta mengefisienkan seluruh aktivitas dalam pemasaran buah nanas di Desa tangkit Baru Kecamatan Sungai Gelam Kabupaten Muaro Jambi sehingga sangat bermanfaat dalam mendukung pengembangan seluruh anggota rantai pasok. Sumberdaya rantai pasok yang dimiliki petani yakni berupa lahan usahatani, peralatan untuk menunjang kegiatan budidaya nanas seperti parang, sabit, cangkul, keranjang panen buah dan lain-lainnya.

Sumber daya fisik yang dimiliki oleh pedagang pengumpul desa meliputi lahan, tempat penyimpangan atau penampungan yang biasanya merupakan rumah milik pedagang sendiri, dan kendaraan pengangkut milik pedagang. Teknologi yang digunakan dan diterapkan oleh petani nanas di Desa Tangkit Baru masih cukup sederhana. Seluruh kegiatan budidaya nanas di daerah penelitian melakukan penanaman, pemupukan dan pemanenan dilakukan secara sederhana menggunakan tenaga manusia. Namun, terdapat beberapa petani yang melakukan pemupukan dan penyemprotan pestisida menggunakan mesin kompresor.

Sumberdaya modal yang dimiliki setiap anggota rantai pasok nanas kebanyakan berasal dari modal pribadi, dan keluarga. Sumber daya 
modal milik petani sebagian besar berasal dari modal pribadi, namun ada pula petani yang memperoleh pinjaman untuk melakukan aktivitas budidaya dari pedagang pengumpul desa langganannya. Modal yang dibutuhkan petani digunakan untuk pengolahan lahan usahatani, biaya pemupukan, obat-obatan dan tenaga kerja. Sumber daya manusia dalam rantai pasok nanas terdiri atas petani nanas, pedagang pengumpul desa, pedagang besar antar kota, pedagang luar jemput, dan pedagang pengecer. Petani merupakan sumber daya manusia yang paling penting dalam rantai pasok, karena petani bertugas untuk memproduksi nanas. Petani responden di daerah penelitian, sebagian besar menggunakan tenaga kerja dalam keluarga dan ada juga yang menggunakan tenaga kerja luar keluarga untuk kegiatan pemupukan, penyemprotan dan penerbasan.

\section{Proses Bisnis Rantai Pasok}

\section{a. Aliran Produk}

Aliran produk buah nanas pada rantai pasok nanas di Desa Tangkit Baru yakni, buah nanas yang dialirkan dari petani kepada pedagang pengumpul desa maupun pedagang besar antar kota. Kemudian nanas tersebut didistribusikan kepada pedagang luar jemput dan pedagang besar luar kota yang selanjutnya akan dialirkan kepada pedagang pengecer yang mengalirkan nanas tersebut kepada konsumen akhir. Lembaga pemasaran pedagang besar antar kota membeli buah nanas dengan tujuan untuk dijual kembali kepada pedagang diluar Provinsi Jambi, yaitu pedagang besar antar kota yang berada di Jakarta dan Bandung. Pedagang besar luar kota yang ada dalam penelitian ini diasumsikan sebagai konsumen akhir karena batasan wilayah penelitian yang hanya mencakup wilayah Kota Jambi saja.

\section{b. Aliran finansial}

Pengelolaan aliran finansial pada rantai pasok nanas di Desa Tangkit Baru dapat dikatakan dikelola dengan baik, namun tidak adanya kesepakatan kontraktual secara tertulis yang terjadi antara petani dan pedagang perantara dalam bermitra pada saat terjadi penundaan pembayaran maupun peminjaman sehingga jika terjadi permasalahan terkait pembayaran tidak dapt diselesaikan dengan jalur hukum karena tidak ada bukti yang kuat. Kesepakatan kontrak yang terjadi di Desa Tangkit Baru didasarkan atas dasar kepercayaan dan faktor kedekatan terhadap mitranya.

\section{c. Aliran informasi}

Aliran informasi yang terjadi di kalangan petani nanas berupa sharing atau saling bertukar pendapat mengenai teknik budidaya nanas, teknik pemupukan, teknik pemanenan, dan informasi mengenai perkembangan harga di pasaran sebagai acuan dalam proses penjualan kepada pedagang dan menjadi acuan dalam proses tawar-menawar antara petani dengan pedagang. Sebaliknya, petani nanas juga menerima informasi dari pedagang pengumpul desa dan pedagang besar antarkota mengenai informasi harga dan perkembangan pasar berdasarkan kualitas buah nanas.

Aliran informasi yang terjadi antara petani nanas dengan lembaga pemasaran yang terlibat seperti pedagang besar antarkota, pedagang pengumpul desa, pedagang pengecer mengalir 2 arah, yaitu informasi yang mengalir dari petani nanas kepada lembaga pemasaran yang terlibat dan informasi yang mengalir dari lembaga pemasaran kepada petani. Informasi yang mengalir dari petani kepada lembaga pemasaran berupa informasi produk atau nanas yang dihasilkan petani tersebut dan mekanisme sistem transaksi.

\section{Kinerja Rantai Pasok}

Kinerja rantai pasok merupakan hasil dari seluruh kegiatan yang dilakukan oleh seluruh anggota pemasaran untuk mencapai tujuan pemasaran, yakni kepuasan konsumen akhir. Kinerja rantai pasok nanas di Desa Tangkit Baru Kecamatan Sungai Gelam diukur dengan efisiensi pemasaran yang mencerminkan penyebaran keuntungan yang diperoleh masing-masing lembaga pemasaran.

\section{Saluran Distribusi Rantai Pasok Nanas di Desa Tangkit Baru Kecamatan Sungai Gelam Kabupaten Muaro Jambi.}

Proses distribusi hasil produksi merupakan bagian yang tidak terpisahkan dalam rantai pasok nanas di Desa Tangkit Baru. Proses distribusi tersebut secara tidak langsung juga akan membentuk suatu saluran yang menghubungkan lembaga-lembaga atau mata rantai yang terlibat dalam rantai pasok nanas di Desa Tangkit Baru Kecamatan Sungai Gelam 
Kabupaten Muaro Jambi. Rantai pasok nanas di Desa Tangkit Baru terdiri dari 5 macam saluran distribusi produk berupa buah nanas segar. Lima macam saluran yang mendistribusikan produk berupa nanas segar tersebut terdiri dari :

a. Saluran satu [Petani - Pedagang Besar Antar Kota - Pedagang Besar Luar Kota]

b. Saluran dua [Petani - Pedagang Pengumpul Dqesa Jemput - Pedagang Pengecer Konsumen]

c. Saluran tiga [Petani - Pedagang Pengecer Konsumen]

d. Saluran empat [Petani - Pedagang Pengumpul Desa Tunggu - Pedagang Luar Jemput - Konsumen]

e. Saluran lima [Petani -Konsumen]

2. Tingkat Efisiensi pada Rantai Pasok Nanas di Desa Tangkit Baru Kecamatan Sungai Gelam Kabupaten Muaro Jambi.
Salah satu indicator untuk mengetahui tingkat keberhasilan rantai pasok adalah dengan mengetahui tingkat efisiensi dari setiap saluran yang ada dalam rantai pasok tersebut. Menurut (Puspitawati dan Wardhani, 2016) menjelaskan bahwa dalam proses pemasaran, semakin efisien apabila kerja lembaga-lembaga pemasaran yang terlibat juga efisien sehingga semua pihak akan semakin mendapat keuntungan.indikator yang dapat digunakan untuk mengukur tingkat efisiensi alam rantai pasok adalah dengan menggunakan pendekatan perhitungan margin pemasaran.

Dalam penelitian ini, ditemukan fenomena bahwa harga buah nanas sangat berfluktuatif sehingga penentuan harga belu dan harga jual yang digunakan untuk menghitung margin pemasaran dari setiap saluran yang ada dalam rantai pasok komoditas nanas di Desa Tangkit Baru Kecamatan Sungai Gelam Kabupaten Muaro Jambi menggunakan

Tabel 1. Margin pemasaran, farmer share, dan rasio B/C saluran I pada rantai pasok nanas di Desa Tangkit Baru

\begin{tabular}{|c|c|c|c|c|c|c|c|}
\hline \multirow{2}{*}{ No } & \multirow{2}{*}{ Lembaga Pemasaran } & \multirow{2}{*}{$\begin{array}{c}\text { Harga } \\
\text { (Rp/Buah) }\end{array}$} & \multicolumn{2}{|c|}{ Share $(\%)$} & \multicolumn{2}{|c|}{$\mathrm{DM}(\%)$} & \multirow{2}{*}{$\mathrm{B} / \mathrm{C}$} \\
\hline & & & Ski & Sbi & Ski & Sbi & \\
\hline \multirow[t]{2}{*}{1} & Petani & & & & & & \\
\hline & Harga Jual & 1.300 & 28,88 & & & & \\
\hline \multirow[t]{7}{*}{2} & Pedagang Besar Antar Kota & & & & & & \\
\hline & Harga Beli & 1.300 & & & & & 0,7 \\
\hline & Biaya Transportasi & 22,50 & & 0,5 & & & 0,55 \\
\hline & Biaya Tenaga Kerja & 17,50 & & 0,39 & & & \\
\hline & Harga Jual & 2.000 & & & & & \\
\hline & Margin Pemasaran & 700 & & & & & \\
\hline & Keuntungan & 660 & 14,66 & & 20,63 & & 16,5 \\
\hline \multirow[t]{9}{*}{3} & Pedagang Pengecer & & & & & & \\
\hline & Harga Beli & 2.000 & & & & & \\
\hline & Biaya Transportasi & 555,33 & & 123,34 & & & 17,4 \\
\hline & Biaya Tenaga Kerja & 150,00 & & 3,33 & & & 4,7 \\
\hline & Biaya Penyusutan & 13,30 & & 0,3 & & & 0,42 \\
\hline & Retribusi & 33,00 & & 0,73 & & & 1,03 \\
\hline & Harga Jual & 4.500 & & & & & \\
\hline & Margin Pemasaran & 2.500 & & & & & \\
\hline & Keuntungan & 1.748 & 38,84 & & 54,63 & & 2,32 \\
\hline \multirow[t]{6}{*}{4} & Konsumen & & & & & & \\
\hline & Harga Beli & 4.500 & & & & & \\
\hline & Total & & 82,38 & 128,59 & 75,25 & & 24,8 \\
\hline & Total Margin & 3.200 & & & & & \\
\hline & Total Biaya Pemasaran & 791.63 & & & & & \\
\hline & Total Keuntungan & 2.408 & & & & & \\
\hline
\end{tabular}

Sumber : Data Primer Diolah, 2019 
harga beli dan harga jual saat penelitian ini berlangsung yaitu harga nanas dalam rentan waktu pada Bulan November - Desember 2019.Menurut (Ardila et al., 2019) besar marjin pemasaran dapat dijadikan salah satu tolak ukur untuk menentukan efisiensi pemasaran. Hasil analisis margin pemasaran pada masing-masing saluran dalam rantai pasok komoditas nanas di Desa Tangkit Baru Kecamatan Sungai Gelam Kabupaten Muaro Jambi dapat dilihat sebagai berikut :

\section{a. Saluran Pemasaran I}

Saluran pemasaran I dalam pendistribusian produk hanya menggunakan satu pedagang perantara saja, yaitu petani - pedagang besar antarkota - pedagang besar luar kota. Nilai margin pemasaran untuk setiap buah nanas pada saluran I adalah Rp 3.200,00. Nilai share atau bagian keuntungan adalah sebesar $82,38 \%$ dan share biaya sebesar $128,59 \%$ sehingga dapat disimpulkan bahwa saluran pemasaran I adalah logis karena nilai share keuntungan yang diperoleh lebih besar dibandingkan dengan share biaya pada saluran pemasaran tersebut. Rata-rata harga jual yang diterima petani adalah sebesar Rp 1.300,00/buah. Nilai PS atau presentase keuntungan petani adalah sebesar $28,88 \%$ dari harga terakhir ditingkat konsumen (pedagang luar kota) yaitu sebesar $\mathrm{Rp}$ 4.500,00/buah. Nilai presentase tersebut menjelaskan bahwa dalam saluran I masih tergolong tidak efisien (Nilai PS $<50 \%$ ). Lebih jelasnya margin pemasaran, farmer share, dan rasio $\mathrm{B} / \mathrm{C}$ yang diterima pada saluran I pada rantai pasok nanas di Desa Tangkit Baru dapat dilihat ada Tabel 1.

\section{b. Saluran Pemasaran II}

Saluran pemasaran II dalam pendistribusian produk hanya menggunakan dua pedagang perantara saja, yaitu petani - pedagang pengumpul desa jemput - pedagang pengecer konsumen. Nilai margin pemasaran untuk setiap buah nanas pada saluran II adalah $\mathrm{Rp}$ $3.750,00$. Nilai share atau bagian keuntungan adalah sebesar $96,24 \%$ dan share biaya sebesar $3,76 \%$ sehingga dapat disimpulkan bahwa saluran pemasaran II adalah logis karena nilai share keuntungan yang diperoleh lebih besar dibandingkan dengan share biaya pada saluran pemasaran tersebut. Rata-rata harga jual yang diterima petani adalah sebesar Rp 3.250,00/buah. Nilai PS atau presentase keuntungan petani adalah sebesar $46,43 \%$ dari harga terakhir ditingkat konsumen yaitu sebesar Rp 7.000,00/buah. Hal ini menjelaskan bahwa nilai presentase dalam saluran II masih tergolong tidak efisien (Nilai PS < 50\%). Lebih jelasnya Margin Pemasaran, Farmer share, dan Rasio B/C yang diterima pada saluran II pada rantai pasok nanas di Desa Tangkit Baru dapat dilihat ada Tabel 2.

\section{c. Saluran Pemasaran III}

Saluran pemasaran III dalam pendistribusian produk hanya menggunakan satu pedagang perantara saja, yaitu petani - pedagang pengecer - konsumen. Nilai margin pemasaran untuk setiap buah nanas pada saluran III adalah $\mathrm{Rp} 1.833,00$. Nilai share atau bagian keuntungan adalah sebesar $124,95 \%$ dan share biaya sebesar 2,07\% sehingga dapat disimpulkan bahwa saluran pemasaran III adalah logis karena nilai share keuntungan yang diperoleh lebih besar dibandingkan dengan share biaya pada saluran pemasaran tersebut. Rata-rata harga jual yang diterima petani adalah sebesar Rp 4.167,00/buah. Nilai PS atau presentase keuntungan petani adalah sebesar $69,45 \%$ dari harga terakhir ditingkat konsumen yaitu sebesar Rp 6.000,00/buah. Hal ini menjelaskan bahwa nilai presentase tersebut menunjukkan bahwa dalam saluran III masih tergolong efisien (Nilai PS > 50\%). Namun, petani menerima harga yang lebih tinggi dari harga yang diterima konsumen. Lebih jelasnya Margin Pemasaran, Farmer share, dan Rasio $\mathrm{B} / \mathrm{C}$ yang diterima pada saluran III pada rantai pasok nanas di Desa Tangkit Baru dapat dilihat ada Tabel 3.

\section{d. Saluran Pemasaran IV}

Saluran pemasaran IV dalam pendistribusian produk hanya menggunakan dua pedagang perantara saja, yaitu petani - pedagang pengumpul desa tunggu - pedagang luar jemput -konsumen. Nilai margin pemasaran untuk setiap buah nanas pada saluran IV adalah Rp 3.458,00. Nilai share atau bagian keuntungan adalah sebesar $96,1 \%$ dan share biaya sebesar $4,14 \%$ sehingga dapat disimpulkan bahwa saluran pemasaran IV adalah logis karena nilai share keuntungan yang diperoleh lebih besar dibandingkan dengan share biaya pada saluran pemasaran 
Yanita, M., Wahyuni, I. : Kinerja dan Efisiensi Rantai Pasok ...

Tabel 2. Margin pemasaran, farmer share, dan Rasio B/C saluran II pada rantai pasok nanas di Desa Tangkit Baru

\begin{tabular}{|c|c|c|c|c|c|c|c|}
\hline \multirow{2}{*}{ No } & \multirow{2}{*}{ Lembaga Pemasaran } & \multirow{2}{*}{$\begin{array}{c}\text { Harga } \\
\text { (Rp/Buah) }\end{array}$} & \multicolumn{2}{|c|}{ Share $(\%)$} & \multicolumn{2}{|c|}{$\mathrm{DM}(\%)$} & \multirow{2}{*}{$\mathrm{B} / \mathrm{C}$} \\
\hline & & & Ski & Sbi & Ski & Sbi & \\
\hline \multirow[t]{2}{*}{1} & Petani & & & & & & \\
\hline & Harga Jual & 3.250 & 46.43 & & & & \\
\hline \multirow[t]{7}{*}{2} & Pedagang Pengumpul Desa Jemput & & & & & & \\
\hline & Harga Beli & 3.250 & & & & & \\
\hline & Biaya Transportasi & 58,00 & & 0,83 & & 1,55 & \\
\hline & Biaya Tenaga Kerja & 51,00 & & 0,73 & & 1,36 & \\
\hline & Harga Jual & 5.000 & & & & & \\
\hline & Margin Pemasaran & 1.750 & & & & & \\
\hline & Keuntungan & 1.641 & 23,44 & & 43,76 & & 15,1 \\
\hline \multirow[t]{9}{*}{3} & Pedagang Pengecer & & & & & & \\
\hline & Harga Beli & 5.000 & & & & & \\
\hline & Biaya Transportasi & 60,66 & & 0,87 & & 1,62 & \\
\hline & Biaya Tenaga Kerja & 22,00 & & 0,31 & & 0,59 & \\
\hline & Biaya Penyusutan & 42,33 & & 0,61 & & 1,13 & \\
\hline & Retribusi & 29,00 & & 0,41 & & 0,8 & \\
\hline & Harga Jual & 7.000 & & & & & \\
\hline & Margin Pemasaran & 2.000 & & & & & \\
\hline & Keuntungan & 1.846 & 26,37 & & 49,23 & & 12 \\
\hline \multirow[t]{6}{*}{4} & Konsumen & & & & & & \\
\hline & Harga Beli & 7.000 & & & & & \\
\hline & Total & & 96,24 & 3,76 & 92,99 & 7,05 & 27,1 \\
\hline & Total Margin & 3.750 & & & & & \\
\hline & Total Biaya Pemasaran & 262,99 & & & & & \\
\hline & Total Keuntungan & 3.487 & & & & & \\
\hline
\end{tabular}

Sumber : Data Primer Diolah, 2019

Tabel 3. Margin pemasaran, farmer share, dan rasio B/C Saluran III pada rantai pasok nanas di Desa Tangkit Baru

\begin{tabular}{|c|c|c|c|c|c|c|c|}
\hline \multirow{2}{*}{ No } & \multirow{2}{*}{ Lembaga Pemasaran } & \multirow{2}{*}{$\begin{array}{c}\text { Harga } \\
\text { (Rp/Buah) }\end{array}$} & \multicolumn{2}{|c|}{ Share $(\%)$} & \multicolumn{2}{|c|}{$\mathrm{DM}(\%)$} & \multirow{2}{*}{$\mathrm{B} / \mathrm{C}$} \\
\hline & & & Ski & Sbi & Ski & Sbi & \\
\hline \multirow[t]{2}{*}{1} & Petani & & & & & & \\
\hline & Harga Jual & 4.167 & 69.45 & & & & \\
\hline \multirow[t]{9}{*}{2} & Pedagang Pengecer & & & & & & \\
\hline & Harga Beli & 4.167 & & & & & \\
\hline & Biaya Transportasi & 58,33 & & 0,97 & & 3,18 & \\
\hline & Biaya Tenaga Kerja & 10,00 & & 0,17 & & 0,55 & \\
\hline & Biaya Penyusutan & 46,66 & & 0,8 & & 2,55 & \\
\hline & Retribusi & 8,00 & & 0,13 & & 0,44 & \\
\hline & Harga Jual & 6.000 & & & & & \\
\hline & Margin Pemasaran & 1.833 & & & & & \\
\hline & Keuntungan & 1.710 & 28,5 & & 93,3 & & 14 \\
\hline \multirow[t]{6}{*}{3} & Konsumen & & & & & & \\
\hline & Harga Beli & 6.000 & & & & & \\
\hline & Total & & 124,95 & 2,07 & 93,3 & 6,72 & 14 \\
\hline & Total Margin & 1.833 & & & & & \\
\hline & Total Biaya Pemasaran & 122,99 & & & & & \\
\hline & Total Keuntungan & 1.710 & & & & & \\
\hline
\end{tabular}

Sumber : Data Primer Diolah, 2019 
Yanita, M., Wahyuni, I. : Kinerja dan Efisiensi Rantai Pasok ...

Tabel 4. Margin pemasaran, farmer share, dan rasio B/C saluran IV pada rantai pasok nanas di Desa Tangkit Baru

\begin{tabular}{|c|c|c|c|c|c|c|c|}
\hline \multirow{2}{*}{ No } & \multirow{2}{*}{ Lembaga Pemasaran } & \multirow{2}{*}{$\begin{array}{c}\text { Harga } \\
\text { (Rp/Buah) }\end{array}$} & \multicolumn{2}{|c|}{ Share $(\%)$} & \multicolumn{2}{|c|}{$\mathrm{DM}(\%)$} & \multirow{2}{*}{$\mathrm{B} / \mathrm{C}$} \\
\hline & & & Ski & Sbi & Ski & Sbi & \\
\hline \multirow[t]{2}{*}{1} & Petani & & & & & & \\
\hline & Harga Jual & 3.264 & 48,6 & & & & \\
\hline \multirow[t]{6}{*}{2} & $\begin{array}{l}\text { Pedagang Pengumpul Desa } \\
\text { Tunggu }\end{array}$ & & & & & & \\
\hline & Harga Beli & 3.264 & & & & & \\
\hline & Biaya Tenaga Kerja & 90,00 & & 1,34 & & 2,6 & \\
\hline & Harga Jual & 4.750 & & & & & \\
\hline & Margin Pemasaran & 1.486 & & & & & \\
\hline & Keuntungan & 1.396 & 20,8 & & 26,7 & & 15,51 \\
\hline \multirow{9}{*}{3} & Pedagang Luar Jemput & & & & & & \\
\hline & Harga Beli & 5.000 & & & & & \\
\hline & Biaya Transportasi & 105,60 & & 1,6 & & 3,05 & \\
\hline & Biaya Tenaga Kerja & 35,00 & & 0,52 & & 1,0 & \\
\hline & Biaya Penyusutan & 30,00 & & 0,45 & & 1 & \\
\hline & Retribusi & 15,40 & & 0,23 & & 0,44 & \\
\hline & Harga Jual & 6.722 & & & & & \\
\hline & Margin Pemasaran & 1.972 & & & & & \\
\hline & Keuntungan & 1.786 & 26,7 & & 49,23 & & 9,6 \\
\hline \multirow[t]{6}{*}{4} & Konsumen & & & & & & \\
\hline & Harga Beli & 6.722 & & & & & \\
\hline & Total & & 96,1 & 4,14 & 92,99 & 8,09 & 25,11 \\
\hline & Total Margin & 3.458 & & & & & \\
\hline & Total Biaya Pemasaran & 276.00 & & & & & \\
\hline & Total Keuntungan & 3.182 & & & & & \\
\hline
\end{tabular}

Sumber : Data Primer Diolah, 2019

tersebut. Rata-rata harga jual yang diterima petani adalah sebesar Rp 3.264,00/buah. Nilai PS atau presentase keuntungan petani adalah sebesar $48,6 \%$ dari harga terakhir ditingkat konsumen yaitu sebesar Rp 6.722,00/buah. Hal ini menjelaskan bahwa nilai presentase tersebut menjelaskan bahwa dalam saluran IV masih tergolong tidak efisien (Nilai PS < 50\%). Lebih jelasnya margin pemasaran, farmer share, dan rasio $\mathrm{B} / \mathrm{C}$ yang diterima pada saluran IV pada rantai pasok nanas di Desa Tangkit Baru dapat dilihat ada Tabel 4.

\section{e. Saluran Pemasaran}

Saluran pemasaran dalam pendistribusian produk termasuk dalam saluran pemasaran langsung, yaitu petani - konsumen. Nilai margin pemasaran untuk setiap buah nanas pada saluran V adalah $\mathrm{Rp} 0$. Nilai share atau bagian keuntungan adalah sebesar 100\% dan share biaya sebesar $3,05 \%$ sehingga dapat disimpulkan bahwa saluran pemasaran $\mathrm{V}$ adalah logis karena nilai share keuntungan yang diperoleh lebih besar dibandingkan dengan share biaya pada saluran pemasaran tersebut. Rata-rata harga jual yang diterima petani adalah sebesar Rp 2.000,00/buah. Nilai PS atau presentase keuntungan petani adalah sebesar $100 \%$ dari harga terakhir ditingkat konsumen yaitu sebesar Rp 2.000,00/buah.

Hal ini menjelaskan bahwa selain menguntungkan bagi petani, konsumen juga diuntungkan dalam saluran ini. Konsumen memiliki kesempatan untuk mendapatkan harga yang lebih murah dibandingkan kepada pedagang perantara lain. Lebih jelasnya Margin Pemasaran, Farmer share, dan Rasio B/C yang diterima pada saluran $\mathrm{V}$ pada rantai pasok nanas di Desa Tangkit Baru dapat dilihat ada Tabel 5.

Efisiensi pemasaran nanas di Desa Tangkit Baru menggambarkan penyebaran keuntungan dan manfaat yang diperoleh oleh masing-masing anggota rantai pasok nanas. 
Yanita, M., Wahyuni, I. : Kinerja dan Efisiensi Rantai Pasok ...

Tabel 5. Margin pemasaran, farmer share, dan rasio B/C saluran V pada rantai pasok nanas di Desa Tangkit Baru

\begin{tabular}{|c|c|c|c|c|c|c|c|c|}
\hline \multirow{2}{*}{ No } & \multirow{2}{*}{ Lembaga Pemasaran } & \multirow{2}{*}{$\begin{array}{c}\text { Harga } \\
\text { (Rp/Buah) }\end{array}$} & \multicolumn{2}{|c|}{ Share (\%) } & \multicolumn{3}{|c|}{$\mathrm{DM}(\%)$} & \multirow{2}{*}{$\mathrm{B} / \mathrm{C}$} \\
\hline & & & Ski & Sbi & Ski & Sbi & & \\
\hline \multirow[t]{3}{*}{1} & Petani & & & & & & & \\
\hline & Harga Jual & 2.000 & 100 & & & & & \\
\hline & Biaya Transportasi & 60,33 & & 3,05 & & & & \\
\hline \multirow[t]{5}{*}{2} & Konsumen & & & & & & & \\
\hline & Harga Beli & 2.000 & & & & & & \\
\hline & Total & & 100 & 3,05 & 0 & & 0 & 32,16 \\
\hline & Total Margin & 0 & & & & & & \\
\hline & Total Biaya Pemasaran & 60,33 & & & & & & \\
\hline
\end{tabular}

Sumber : Data Primer Diolah, 2019

Tabel 6. Nilai efisiensi pemasaran pada masing-masing saluran pemasaran nanas di Desa Tangkit Baru

\begin{tabular}{cccccc}
\hline Saluran Pemasaran & $\begin{array}{c}\text { Harga Jual }^{\mathrm{b}} \\
\text { (Rp/Buah) }\end{array}$ & $\begin{array}{c}\text { Total Biaya } \\
\text { (Rp/Buah) }\end{array}$ & Margin $^{\mathrm{c}}$ & $\mathrm{FS}^{\mathrm{d}}(\%)$ & $\mathrm{Li}^{\mathrm{C}} / \mathrm{Ci}^{\mathrm{e}}$ \\
\hline Saluran 1 & 1300 & 792 & 3200 & 28,88 & 3,04 \\
Saluran 2 & 3250 & 263 & 3750 & 56,43 & 13,3 \\
Saluran 3 & 4167 & 123 & 1833 & 69,45 & 14 \\
Saluran 4 & 3264 & 276 & 3458 & 48,6 & 11,5 \\
Saluran 5 & 2000 & 60,33 & 0 & 100 & 32,2 \\
\hline
\end{tabular}

Sumber : Data Primer Diolah, $2019 ;{ }^{\mathrm{b}}$ di tingkat produsen pada masing-masing saluran pemasaran; ${ }^{\mathrm{c}}$ total margin dari harga di tingkat konsumen akhir pada masing-masing saluran pemasaran; ${ }^{\mathrm{d}}$ Farmer's share; ${ }^{\mathrm{e}}$ Rasio keuntungan terhadap biaya pemasaran (total)

Tabel 6 menyajikan nilai efisiensi pemasaran untuk masing-masing pola saluran pemasaran.

Berdasarkan penelitian, dalam penjualan produk buah nanas segar, terdapat dua tujuan akhir pemasaran, yakni pengolah dan konsumen akhir. Namun tidak semua petani memiliki akses langsung untuk menjual produknya kepada konsumen akhir karena keterbatasan biaya dan pasar. Menurut (Rahman et al., 2020) terdapat empat motif atau alasan kenapa petani menjual hasil pertaniannya ke pedagang pengecer ataupun ke pedagang pengumpul, yaitu adanya ikatan keluarga dan ikatan sosial, keterbatasan modal, jaminan pemasaran dalam situasi harga yang fluktuasi, bantuan dalam proses penyotiran, penyusunan dan pengangkutan. Dilihat dari nilai margin pemasaran, farmer's share dan rasio keuntungan terhadap biaya, saluran pemasaran yang dapat relatife efisien dan menguntungkan untuk tujuan penjualan ke konsumen akhir jika dilihat dari kemudahan akses adalah saluran tiga. Saluran tiga memiliki nilai margin pemasaran sebesar Rp 1.833, farmer's share $69,45 \%$, dan keuntungan terhadap biaya sebesar 14\%. Sementara itu, untuk penjualan buah nanas kepada pengolah, saluran lima merupakan saluran yang paling menguntungkan dengan margin pemasaran sebesar 0, farmer's share sebesar $100 \%$ dan rasio keuntungan terhadap biaya pemasaran sebesar $32,2 \%$. Namun petani yang dapat menjual buah nanas langsung kepada pengolah hanyalah petani yang sudah menjadi langganan dengan pihak pengolah.

\section{KESIMPULAN}

Analisis rantai pasok dengan menggunakan pendekatan Food Supply Chain Network (FSCN) menunjukkan bahwa sistem pemasaran nanas di Desa Tangkit Baru Kecamatan Sungai Gelam Kabupaten Muaro Jambi belum menerapkan pengelolaan rantai pasok modern. Saluran pemasaran nanas di Desa Tangkit Baru terdiri atas lima saluran pemasaran dan melibatkan pelaku pemasaran mulai dari petani, pedagang besar antar kota, pedagang pengumpul desa, pedagang luar jemput, pedagang pengecer dan agroindustri. Rantai pasok nanas di Desa Tangkit Baru Kecamatan Sungai Gelam terdiri dari lima macam saluran yang mendistribusikan produk berupa buah nanas dalam bentuk segar dan satu di distribusikan produk olahan dalam bentuk dodol nanas, selai nanas, nanas goreng yang 
diolah oleh agroindustri yang berada disekitaran Desa Tangkit Baru. Saluran distribusi yang terdapat pada rantai pasok nanas di Desa Tangkit Baru adalah efisien jika dilihat dari a0 Nilai share keuntungan yang diperoleh pada setiap saluran lebih besar bila dibandingkan dengan share biaya (ski>sbi) dan; b0 Nilai share bagian harga yang diterima oleh setiap mata rantai dinilai adil atau proposional sesuai dengan fungsi yang dilakukan oleh setiap mata rantai. Pengukuran kinerja rantai pasok nanas di Desa Tangkit Baru menunjukkan pemasaran nanas di Desa Tangkit Baru efisien. Seluruh lembaga pemasaran yang terlibat menjalankan fungsifungsi pemasaran dengan cukup baik, penentuan harga nanas di tentukan oleh mekanisme pasar, sebagian besar pembayaran dilakukan secara tunai dan terdapat hubungan yang baik antar lembaga pemasaran yang terlibat. Saluran pemasaran yang memiliki sebaran total margin terkecil, farmer share terbesar yaitu sebesar $100 \%$ dan total rasio keuntungan terhadap biaya yang besar yaitu sebesar 32,2\% terdapat pada saluran pemasaran 5 , sehingga saluran 5 merupakan saluran pemasaran yang paling efisien.

\section{DAFTAR PUSTAKA}

Ardila, D. D., Agustina, T., Subekti, S. (2019). Saluran dan margin pemasaran Kopi Cap Lereng Tancak Kabupaten Bondowoso. SEPA: Jurnal Sosial Ekonomi Pertanian Dan Agribisnis, 15(2), 116-127. https://doi.org/10.20961/sepa.v15i2.2743 0 .

Dilana. (2013). Pemasaran dan Nilai Tambah Kakao. Prosiding Simposium Nasional Ekonomi Kakao. Retrieved from http://repository.ipb.ac.id/handle/123456 $789 / 69315$.

Drajat, B., Agustian, A., \& Supriatna, A. (2007). Export and competitiveness of Indonesian coffee bean in international market: Strategic implication for the development of organic coffee bean. Pelita Perkebunan (a Coffee and Cocoa Research Journal), 23(2). https://doi. org/10.22302/iccri.jur.pelitaperkebunan. v23i 2.88

Lambert, D. M., \& Enz, M. G. (2017). Issues in supply chain management: Progress and potential. Industrial Marketing Management, 62, 1-16. https://doi.org/ 10.1016/j.indmarman.2016.12.002

Nguyen, K. T. (2020). the Effect of Institutional Context on the Governance of Emergent Supply Chains: a Case Study of Cassava Sector in Vietnam. SEPA: Jurnal Sosial Ekonomi Pertanian Dan Agribisnis, 16(2), 185. https://doi. org/10.20961/sepa.v16i2.35718.

Puspitawati, I. R., \& Wardhani, R. M. (2016). Analisis efisiensi pemasaran kentang (Solanum Tuerosum L.) di Kabupaten Magetan. Ilmu Pertanian, Kehutanan dan Agroteknologi, 17(1).

Rahman, Y. A., Safitri, R., \& Cahyono, E. D. (2020). Motif petani dalam memilih pasar (Kasus di Sub Terminal Agribisnis Terpadu Taniran Kabupaten Hulu Sungai Selatan). SEPA: Jurnal Sosial Ekonomi Pertanian Dan Agribisnis, 17(1), 33-39.

Rasihen, Y. (2018). Analisis efisiensi dan perilaku pasar gula aren di Kecamatan Rambah Samo Kabupaten Rokan Hulu. SEPA: Jurnal Sosial Ekonomi Pertanian Dan Agribisnis, 14(1), 47. https://doi. org/10.20961/sepa.v14i1.21044.

Vorst, V. der. (2014). Performance measurement in agri-food supply-chain networks - An overview. In Ondersteijn, C.J.M., Wijnands, J.H.M., Huirne, R.B.M., van Kooten, O. (Eds.), Quantifying the Agri-Food supply Chain (pp.15-26). New York: Springer. https://doi.org/10.1007/1-4020-4693-6. 